\title{
REAKCJE PRZEDSIĘBIORSTW NA OBCIĄŻENIA PODATKOWE (NA PRZYKLADZIE PODATKU OD TOWARÓW I USŁUG)
}

\begin{abstract}
Streszczenie
W artykule przedstawiono autorskie (własne) ujęcie reakcji przedsiębiorstw na obciążenia podatkowe. Założono, że z punktu widzenia przedsiębiorstwa najbardziej pożądane jest stosowanie strategii podatkowej. Zaproponowano przy tym jej definicję. W artykule skoncentrowano się na podatku od towarów i usług, za cel przyjmując identyfikację skutków tego podatku w finansach przedsiębiorstwa w aspekcie rozpatrywanych reakcji. Przyjęto tezę, że w zakresie podatku od towarów i usług jest możliwe stosowanie strategii podatkowej, co wykazano (analiza w ujęciu teoretycznym i prawnym) oraz poddano konfrontacji z praktyką (analiza wybranych danych empirycznych).
\end{abstract}

Słowa kluczowe: strategia podatkowa, przedsiębiorstwo, podatek od towarów i usług

\section{REACTIONS OF ENTERPRISES TO TAX BURDEN: THE CASE OF GOODS AND SERVICES TAX}

\section{Summary}

The paper presents an original perspective on how enterprises react to tax burden. The assumption states that from the point of view of an enterprise, the use of a tax strategy is the most desirable option. A definition of tax strategy is proposed. The paper centres around the Goods and Services Tax. The author's aim is to identify the effects of the Goods and Services Tax in enterprise financial management with regard to the researched reactions. The thesis is that in the case of the Goods and Services Tax it is possible to apply a tax strategy. This is demonstrated by analysis of both theoretical and legal issues relevant to the problem, and validated practically by means of empirical data analysis.

Key words: tax strategy, enterprise, Goods and Services Tax

DOI: $10.15290 /$ ose.2015.01.73.12

\section{Wstęp}

Funkcjonowanie przedsiębiorstwa w warunkach gospodarki rynkowej jest zdeterminowane bardzo wieloma czynnikami zarówno wewnętrznymi, jak i zewnętrznymi. Uwarunkowania zewnętrzne to określone elementy otoczenia, które mogą oddziaływać na działalność przedsiębiorstwa w sposób bądź stymulujący, bądź destrukcyjny. Kieru-

${ }^{1}$ Prof. dr hab. Teresa Famulska - Wydział Finansów i Ubezpieczeń, Uniwersytet Ekonomiczny w Katowicach; e-mail: teresa.famulska@ue.katowice.pl. 
nek i siła tego oddziaływania w przypadku konkretnego przedsiębiorstwa zależą między innymi od jego sytuacji wewnętrznej. Zatem utrzymanie stabilnej pozycji konkurencyjnej przez przedsiębiorstwo wymaga nie tylko identyfikacji złożonego otoczenia i zachodzacych w nim zmian, ale również ciagłej jego analizy i oceny w kontekście podejmowania różnorodnych decyzji. W ujęciu ogólnym można wyróżnić otoczenie bliższe (rynkowe) oraz dalsze (makroekonomiczne) ${ }^{2}$, którego szczególnym elementem są obciążenia podatkowe. Stanowią one istotne zewnętrzne ograniczenie działalności przedsiębiorstwa tak bieżącej, jak i rozwojowej, bowiem w sposób przymusowy zmniejszają środki pozostające w jego dyspozycji. Poszczególne podatki wywołują zróżnicowane skutki w finansach przedsiębiorstw i tym samym różnie oddziałują na ich funkcjonowanie. W niniejszym artykule skoncentrowano się na podatku od towarów i usług, za cel przyjmując identyfikację skutków tego podatku w finansach przedsiębiorstwa w aspekcie reakcji na obciążenia fiskalne. Przedsiębiorstwa, co do zasady, nie zachowuja się biernie wobec pobrań podatkowych, stąd rozważania zmierzają również do rozpoznania możliwości stosowania strategii podatkowej w ramach rozpatrywanej daniny publicznej.

\section{Reakcje przedsiębiorstw na obciążenia podatkowe}

Z punktu widzenia władzy publicznej opodatkowanie przedsiębiorstw jest podporządkowane pierwotnej i podstawowej funkcji podatków, jaką jest funkcja fiskalna. Z perspektywy przedsiębiorstw znajduje ona symetryczne odzwierciedlenie w funkcji regulacyjnej. Podatki regulują (in minus) poziom zasobów pieniężnych przedsiębiorstw, przy czym jest to regulacja: jednostronna, przymusowa, bezzwrotna i nieodpłatna. Sama istota kategorii podatku, w tym jego dwoisty charakter, generuje skonkretyzowana sprzeczność interesów władzy publicznej i przedsiębiorstw. Zatem to, czy oczekiwany przez władzę publiczną efekt fiskalny określonego podatku zostanie zrealizowany, w znaczącym stopniu jest zdeterminowane reakcja przedsiębiorstwa na to obciażenie.

Przedsiębiorstwo może przyjąc różne postawy wobec podatku, w konsekwencji których będą także zróżnicowane skutki tak dla władzy publicznej, jak i samych przedsiębiorstw (rysunek 1.). Przyjęte postawy wiążą się z określoną reakcją na podatek, która może być:

- zapłacenie należnego podatku,

- ucieczka od podatku,

- $\quad$ stosowanie strategii podatkowej [Famulska, 1998, s. 23].

${ }^{2} \mathrm{~W}$ literaturze przedmiotu zwraca się również uwagę na globalny charakter otoczenia, np.: [Giachetti, 2010, s. 18]. 


\section{Reakcja przedsiębiorstwa na podatek a efekt fiskalny}

RYSUNEK 1.
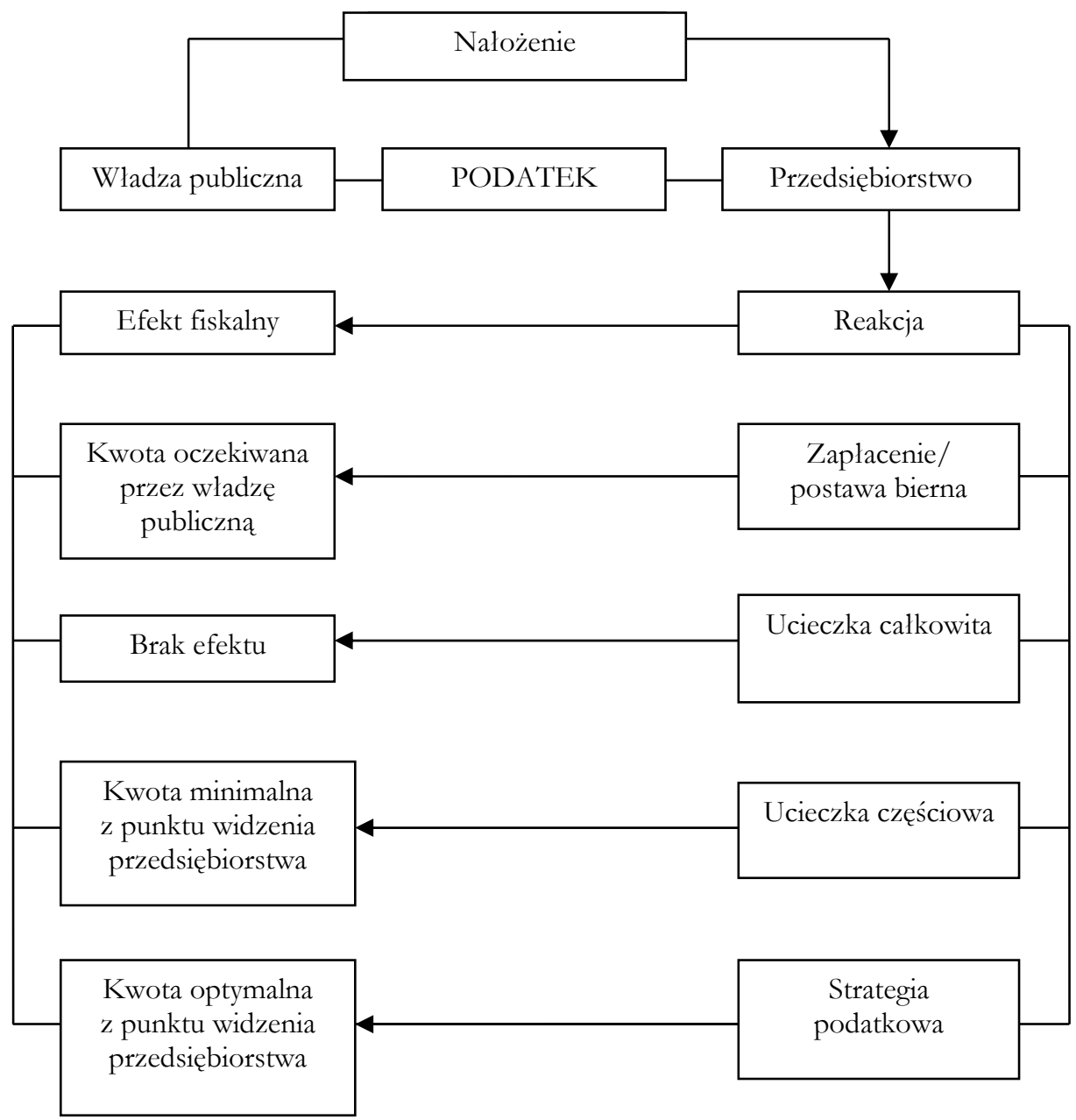

Źródło: opracowanie własne na podstawie: [Famulska, 1993, s. 9].

Zapłacenie przez przedsiębiorstwo podatku bez podejmowania jakichkolwiek działań w celu zmniejszenia ciężaru podatkowego jest najbardziej pożądana postawa z punktu widzenia władzy publicznej. Zapłacenie można określić jako przystosowanie do obowiązków podatkowych ${ }^{3}$. Postawy tej nie można utożsamiać z zupełną biernością

${ }^{3}$ Rozpatrując przystosowanie się do obowiązków podatkowych podatnika - osoby fizycznej, należy rozróżnić: uleganie, internalizację i identyfikację. Uleganie jest pozornym, zewnętrznym przystosowaniem się do wymagań władzy publicznej, jednak nie wynika ono z przekonania o słuszności uiszczania podatków, 
wobec nałożonego podatku. W praktyce przedsiębiorstwo przed rozliczeniem się z określonego zobowiązania podatkowego przeprowadza weryfikację kwoty do zapłacenia, rozpoznaje także ewentualne ulgi i zwolnienia. Sprawdzenie takie może stać się punktem wyjścia do ucieczki od podatku, która przybiera różne formy. Między innymi, zgodnie z kryterium wielkości ciężaru podatkowego, którego nie chce ponieść przedsiębiorstwo, wyróżnia się ucieczkę całkowitą oraz ucieczkę częściową. Przyjmując kryterium definitywności, ucieczka od podatku może być definitywna (przedsiębiorstwo nie płaci całości lub części nałożonego podatku) lub czasowa (przedsiębiorstwo opóźnia wywiązanie się ze zobowiązań podatkowych). Z kolei, według kryterium prawnego, omijanie płacenia podatków może dokonywać się albo bez naruszenia prawa (unikanie podatków, ang. tax avoidance), albo z naruszeniem prawa (uchylanie się od podatku, ang. tax evasion). W praktyce podział na unikanie i uchylanie się od opodatkowania jest nieostry [Kudła, 2013, s. 248]. Należy również zauważyć, że ucieczka od podatku w każdej formie jest zjawiskiem niepożądanym, które wywołuje wiele negatywnych następstw [Gomułowicz, 2013, s. 121-123]. Zakłóca ono funkcjonowanie mechanizmu zarówno finansów publicznych, jak i prywatnych. Dla przedsiębiorstw, które uiszczają podatki, fakt ich omijania przez inne często może być równoznaczny z mniejszą konkurencyjnością na rynku.

Jedną z możliwości reagowania na obciążenia podatkowe przez przedsiębiorstwa jest stosowanie strategii podatkowej. Oznacza ona traktowanie podatków jako zewnętrznych ograniczeń działalności, przy czym zmierza ona do ponoszenia optymalnego ciężaru podatkowego. Większość podstawowych - długoterminowych i bieżących decyzji w prawidłowo funkcjonującym przedsiębiorstwie powinna uwzględniać element podatków. W zakresie danego problemu decyzyjnego rozważa się warianty rozwiązań, poza tym dla każdego z nich analizuje się następstwa podatkowe $\mathrm{i}$ inne dla przedsiębiorstwa. Wato zaznaczyć, że podatki nie są jedynym czynnikiem wpływającym na dokonywanie wyborów w przedsiębiorstwie, a tylko jednym z wielu, dlatego podatek podlega rozważeniu wariantowemu z innymi zmiennymi. Zatem strategia podatkowa oznacza zapłacenie należnego podatku, ale poprzedzone decyzją, która determinuje jego wielkość. Stosowanie strategii podatkowej nie jest równoznaczne z poszukiwaniem luk prawnych czy ucieczki przed podatkiem, lecz jest korzystaniem z ulg, zwolnień $\mathrm{i}$ innych udogodnień, które są przewidziane prawnie. Strategia podatkowa, obok wyważania określonych decyzji w aspekcie podatkowym, obejmuje analizę poszczególnych rozwiązań podatkowych i ewentualnych korzyści płynących z dostosowania się do oczekiwań ustawodawcy wyrażonych określonymi preferencjami. Stosowanie strategii podatkowej wymaga od służb finansowych przedsiębiorstw znajomości obowiązujących rozwiązań podatkowych, powiązań pomiędzy poszczególnymi podatkami, a także związku systemu podatkowego z prawem gospodarczym, bankowym itp.

Reakcja przedsiębiorstw na obciążenia podatkowe ściśle wiąże się z możliwościa ich przerzucenia. Rozważając przerzucalność podatkową, można wskazać różne jej

lecz z obawy przed konsekwencjami. Internalizacja oznacza zmianę przekonań oraz integrację wymagań podatkowych z systemem wartości jednostki. Z kolei identyfikacja wiąże się ze zmianą przekonań po to, aby zyskać akceptację grupy odniesienia bądź cenionych autorytetów i znaczących osób. Szerzej: [Famulska, 1998, s. 24]. 
ujęcia (rysunek 2.). W szczególności warto odnotować rodzaje przerzucalności wyodrębnione na podstawie kryterium aktywności przedsiębiorstwa. W związku z tym przerzucalność rzeczywista ma miejsce wtedy, gdy jest wynikiem inicjatywy podjętej przez przedsiębiorstwo, natomiast przerzucalność pozorna to taka, którą z góry założył ustawodawca i jest wynikiem określonej konstrukcji podatku [Szczodrowski, 2012, s. 20]. Należy zauważyć, że w okresach ożywienia gospodarczego istnieją większe możliwości przerzucania podatków w przód (na nabywców), co równocześnie zmniejsza skłonność do ucieczki przed podatkiem [Witczak, 2013, s. 242].

RYSUNEK 2.

Rodzaje przerzucalności podatkowej według różnych kryteriów

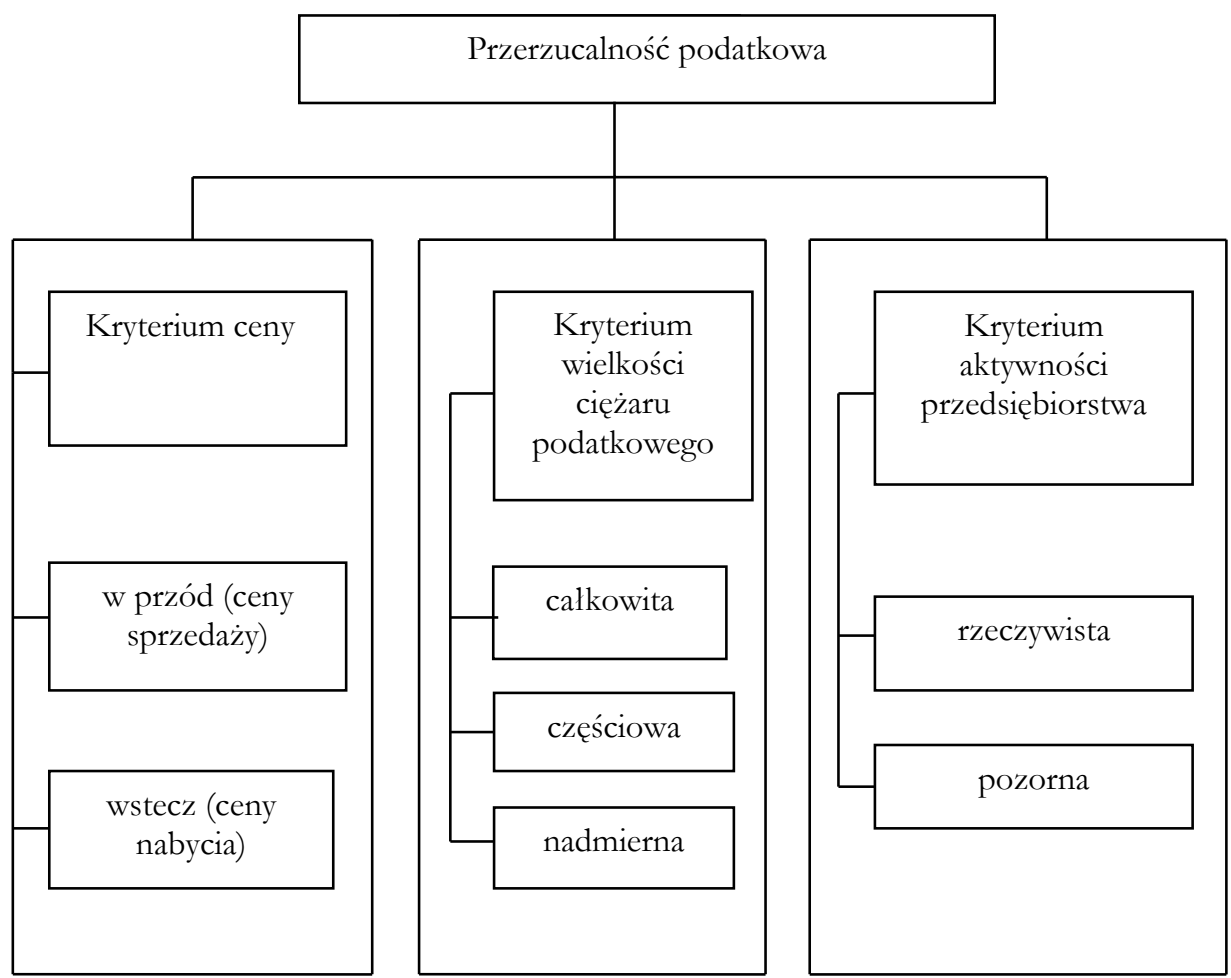

Źródło: opracowanie własne.

W rozpatrywanym problemie reakcji przedsiębiorstw na dotyczące ich podatki jest również ważna identyfikacja skutków obciążeń podatkowych dla finansów przedsiębiorstw. Zróżnicowane ciężary podatkowe implikują bowiem różne konsekwencje $\mathrm{w}$ finansach przedsiębiorstwa. Wynika to nie tylko z wielkości podatku, przedmiotu opodatkowania, momentu powstania obowiazku podatkowego itp., ale również z umiejscowienia ciężaru fiskalnego w finansach przedsiębiorstwa. Przyjmując uproszczone ujęcie 
finansów przedsiębiorstwa, można wyodrębnić dwa strumienie pieniężne: (1) koszty, (2) przychody oraz ich wypadkowa - dochód (stratę). Ujęcie to można umownie nazwać księgowo-podatkowym. Za istotne należy uznać ustalenie relacji między tymi kategoriami a ciężarami podatkowymi nałożonymi na przedsiębiorstwo przez władzę publiczna. Przede wszystkim trzeba odnotować, że wyodrębnionym kategoriom z obszaru finansów przedsiębiorstw odpowiadają określone grupy podatków, a są to podatki: kosztowe, przychodowe, dochodowe.

Specyfika obciążeń kosztowych polega na tym, że łączą się one głównie z różnymi elementami zaangażowanymi w działalności gospodarczej przedsiębiorstwa. Dotycza one określonego majątku, sa nimi także ciężary fiskalne związane $z$ wynagrodzeniami. Zakres oddziaływania obciązeń kosztowych na finanse przedsiębiorstw jest zależny głównie od rodzaju prowadzonej działalności gospodarczej i wynikającej z niego konieczności wykorzystywania różnych czynników, z którymi prawo wiąże powstanie obowiazku podatkowego. Obciążenia kosztowe mają określony wymiar in minus w finansach przedsiębiorstwa. Warto przy tym zwrócić uwagę na swoisty walor (wymiar in plus) mający miejsce wówczas, gdy mogą one być uznane za koszty uzyskania przychodu dla potrzeb ustalenia podstawy opodatkowania podatkiem dochodowym.

Kolejna grupę obciążeń stanowią podatki przychodowe, zwane również podatkami od obrotu lub od sprzedaży. W założeniu podatki te poprzez cenę zostaja przerzucane na nabywców, zatem maja podobnie jak obciażenia kosztowe, charakter cenotwórczy i wpływają na rentowność sprzedaży.

Przedmiotem opodatkowania pozostaje zarazem dochód przedsiębiorstwa. Obciążenie fiskalne dochodu - w sensie ogólnym - jest najbardziej czytelną konstrukcja z punktu widzenia finansów przedsiębiorstwa, bowiem zmniejsza wypracowaną w danym okresie nadwyżkę. W ujęciu szczegółowym jest kategorią bardziej złożoną która powoduje wielorakie skutki nie tylko w rentowności, ale także w płynności finansowej przedsiębiorstw. Równocześnie należy zauważyć, iż ustalenie wyniku finansowego dla potrzeb podatkowych nie jest tożsame $z$ wynikiem obliczonym zgodnie z prawem bilansowym. Opodatkowanie dochodu jest zależne głównie od formy prawnej prowadzonej działalności gospodarczej. Zasadniczo obowiązuja podatek dochodowy od osób prawnych oraz podatek dochodowy od osób fizycznych. Podatki dochodowe obciążaja każdy rodzaj osiagniętego dochodu i przyczyniają się do ograniczenia możliwości finansowych przedsiębiorstw zarówno w zakresie działań bieżących, jak i długoterminowych. Skutkuja jednocześnie zmniejszeniem bezpośrednich korzyści właścicieli, ograniczając zyski z zaangażowanego przez nich kapitału.

Syntetyczna identyfikacja relacji określonych grup obciążeń podatkowych z finansami przedsiębiorstw uprawnia do konstatacji, że podatki istotnie oddziałuja na finanse przedsiębiorstw, a w konsekwencji są ważnym uwarunkowaniem ich funkcjonowania. Zauważa się również, że różne podatki o tej samej wielkości mają inny wymiar finansowy dla przedsiębiorstw, co z kolei implikuje zróżnicowane reakcje na te obciążenia. 


\section{Oddziaływanie podatku od towarów i usług na finanse przedsiębiorstw w aspekcie reakcji podatnika}

Podejmując zagadnienie oddziaływania podatku od towarów i usług na finanse przedsiębiorstw i związanej z nim reakcji ${ }^{4}$, należy wskazać na kwestię niezbędnej wiedzy podatkowej, w tym w zakresie rozpatrywanego podatku. Ważne jest rozpoznanie, czy podatek ten ciąży na przedsiębiorstwie, jakie są tryb i terminy jego rozliczenia, w jaki sposób ustalić zobowiązania podatkowe itp. Ogólnie, jest konieczna znajomość określonych przepisów prawa podatkowego, właściwe - czyli zgodne z intencja prawodawcy - ich zrozumienie, a w konsekwencji poprawne stosowanie. O tym, że jest to bardzo trudne, świadczą urzędowe interpretacje przepisów prawa podatkowego ${ }^{5}$, wydawane przez ministra finansów (tabele: 1., 2., 3.).

TABELA 1.

Liczba wydanych, indywidualnych interpretacji podatkowych w biurach Krajowej Informacji Podatkowej w podziale na poszczególne podatki w latach 2007-2013

\begin{tabular}{|c|c|c|c|c|c|c|c|c|}
\hline \multirow[b]{2}{*}{ ROK } & \multirow{2}{*}{ 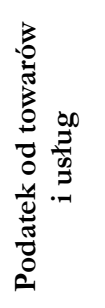 } & \multirow{2}{*}{ 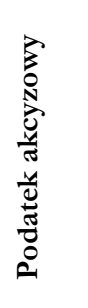 } & \multirow{2}{*}{ 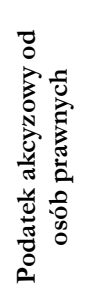 } & \multicolumn{2}{|c|}{$\begin{array}{l}\text { Podatek dochodo- } \\
\text { wy od osób fizycz- } \\
\text { nych }\end{array}$} & \multirow{2}{*}{ 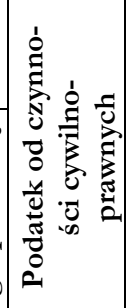 } & \multirow{2}{*}{ 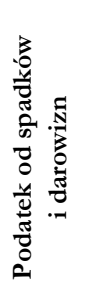 } & \multirow[b]{2}{*}{ RAZEM } \\
\hline & & & & 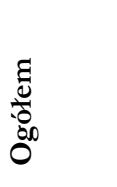 & 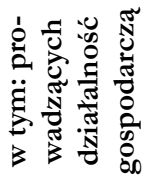 & & & \\
\hline $2007 *$ & 2296 & 87 & 792 & 1087 & 584 & 102 & 50 & 4414 \\
\hline 2008 & 11071 & 321 & 4339 & 7779 & 3224 & 533 & 186 & 24229 \\
\hline 2009 & 12211 & 802 & 5455 & 8701 & 3752 & 786 & 198 & 28153 \\
\hline 2010 & 12986 & 458 & 6162 & 10248 & 4227 & 771 & 295 & 30920 \\
\hline 2011 & 17037 & 383 & 6217 & 11064 & 4355 & 954 & 274 & 35929 \\
\hline 2012 & 16367 & 878 & 5910 & 12365 & 4981 & 990 & 306 & 36816 \\
\hline 2013 & 16717 & 447 & 6301 & 11462 & 5016 & 985 & 235 & 36147 \\
\hline Razem & 88685 & 3376 & 35176 & 62706 & 26139 & 5121 & 1544 & 196608 \\
\hline
\end{tabular}

* Interpretacje wydane w okresie VII -XII 2007 rok

Źródło: opracowanie własne na podstawie sprawozdań wewnętrznych Ministerstwa Finansów (materiały niepublikowane).

\footnotetext{
${ }^{4}$ Rozważaniami nie objęto uchylania się od podatku od towarów i usług. Szerzej: [Straty Skarbu Państwa w VAT, 2013].

${ }^{5}$ Instytucja interpretacji podatkowych została wprowadzona do polskiego systemu podatkowego w 1997 roku w odpowiedzi na liczne postulaty podatników, głównie przedsiębiorców mających problemy ze stosowaniem niejasnych, złożonych, często niespójnych regulacji podatkowych. Nosiła ona różne nazwy, zróżnicowane były konsekwencje skorzystania z niej przez przedsiębiorcę, podlegała licznym zmianom i w efekcie w 2007 roku (od lipca) wprowadzono scentralizowany system indywidualnych interpretacji przepisów prawa podatkowego wydawanych przez ministra finansów. Szerzej: [Oddrialywanie instytucij ..., s. 35-122].
} 
TABELA 2.

Liczba wydanych, indywidualnych interpretacji podatkowych w biurach Krajowej Informacji Podatkowej dla osób prowadzących działalność gospodarczą w latach 2007-2013

\begin{tabular}{|l|c|c|c|}
\hline Rok & $\begin{array}{c}\text { Interpretacje } \\
\text { ogółem (1) }\end{array}$ & $\begin{array}{c}\text { Interpretacje dla podmio- } \\
\text { tów prowadzących działal- } \\
\text { ność gospodarczą (2) }\end{array}$ & \% (2 do 1) \\
\hline $2007 *$ & 4414 & 3759 & 85,16 \\
2008 & 24229 & 18955 & 78,23 \\
2009 & 28153 & 22220 & 78,93 \\
2010 & 30920 & 23833 & 77,08 \\
2011 & 35929 & 27992 & 77,91 \\
2012 & 36816 & 28136 & 76,42 \\
2013 & 36147 & 28481 & 78,79 \\
\hline
\end{tabular}

* Interpretacje wydane w okresie VII -XII 2007 rok

Źródło: opracowanie własne na podstawie sprawozdań wewnętrznych Ministerstwa Finansów (materiały niepublikowane).

TABELA 3.

Struktura przedmiotowa (w \%) wydanych, indywidualnych interpretacji podatkowych w biurach Krajowej Informacji Podatkowej dla osób prowadzących działalność gospodarczą w latach 2007-2013

\begin{tabular}{|l|c|c|c|c|}
\hline Lata & VAT & Akcyza & CIT & PIT \\
\hline $2007^{*}$ & 61,08 & 2,31 & 21,07 & 15,54 \\
2008 & 58,41 & 1,69 & 22,89 & 17,07 \\
2009 & 54,95 & 3,61 & 24,55 & 16,89 \\
2010 & 54,49 & 1,92 & 25,85 & 17,74 \\
2011 & 60,86 & 1,37 & 22,21 & 15,56 \\
2012 & 58,17 & 3,12 & 21,01 & 17,70 \\
2013 & 58,70 & 1,57 & 22,12 & 17,61 \\
\hline
\end{tabular}

* Interpretacje wydane w okresie VII -XII 2007 rok

Źródło: opracowanie własne na podstawie sprawozdań wewnętrznych Ministerstwa Finansów (materiały niepublikowane).

Z prezentowanych danych wynika, że w ogólnej sumie wydanych, indywidualnych interpretacji podatkowych w kraju w okresie 2007-20136 najwięcej (ponad 45\%) stanowiły interpretacje w zakresie podatku od towarów i usług. Za zasadne należy uznać zawężenie analizy do interpretacji wydanych na rzecz podmiotów prowadzących działalność gospodarcza. Obejmowały one średnio około $78 \%$ wszystkich wydanych interpretacji. Dane te dowodza, że z indywidualnych interpretacji podatkowych korzystaja

${ }^{6}$ Jest to okres od lipca 2007 roku, czyli od początku funkcjonowania instytucji interpretacji przepisów prawa podatkowego w obowiązującym kształcie. 
przede wszystkim przedsiębiorstwa. Stanowią one zatem dominująca grupę beneficjentów tej instytucji. Rozpatrując strukturę przedmiotową wydanych interpretacji dla podmiotów gospodarczych, można zauważyć, że najwięcej problemów mają one z odczytaniem i zastosowaniem przepisów w zakresie podatków od towarów i usług - średnio ponad 58\% wszystkich wydanych interpretacji dla przedsiębiorstw dotyczy tego podatku. Jest to związane $z$ bardzo dużym skomplikowaniem regulacji podatkowych w tym zakresie, ścisłą harmonizacją z normami unijnymi oraz powszechnościa i wysoce fiskalnym charakterem podatku od towarów i usług. Podatek ten wywołuje istotne skutki w finansach przedsiębiorstw, dlatego też przedsiębiorcy dążą do ograniczania ryzyka podatkowego, korzystając $z$ instytucji zapewniających im ochronę, w sytuacji dostosowania się do stanowiska prezentowanego $\mathrm{w}$ interpretacji przez ministra finansów. Rozkład wydanych interpretacji w zakresie podatku od towarów i usług w ujęciu czasowym wskazuje na ścisły związek zainteresowania przedsiębiorstw interpretacja w tym podatku $\mathrm{z}$ dokonywanymi zmianami w regulacjach prawnych, które go dotycza. Potwierdzają to na przykład dane z roku 2011, kiedy wprowadzono zasadnicze zmiany.

O tym, że podatek od towarów i usług jest dla przedsiębiorstw skomplikowany, i tym samym trudny, świadczą również wyniki badań przeprowadzonych w grupie 50 przedsiębiorstw? . Badane podmioty bez względu na to, czy rozliczają się z obciążeń fiskalnych samodzielnie, czy za pośrednictwem biura rachunkowego, oceniły regulacje prawne w zakresie podatku od towarów i usług negatywnie (ponad połowa) lub raczej negatywnie (prawie połowa). Tylko jedno przedsiębiorstwo spośród ogółu badanych skłoniło się do oceny raczej pozytywnej. Znamienny jest fakt, że żadne przedsiębiorstwo nie wyraziło jednoznacznie pozytywnej opinii na temat tych rozwiązań. Podatek od towarów i usług jest znacznym obciążeniem dla przedsiębiorstw nie tylko w wymiarze ciężaru technicznego (konieczność obsługi), ale również ciężaru ekonomicznego (ograniczenie środków, płynność finansowa). Zasadnicze oddziaływanie podatku od towarów i usług na finanse przedsiębiorstw wynika z jego cenotwórczego charakteru. Podatek ten jest elementem ceny, tym samym wielkość stawki tego podatku wpływa na wysokość ceny, a w konsekwencji oddziałuje na popyt. Można zatem stwierdzić, że stawka podatku jest czynnikiem wpływającym na wielkość i rentowność sprzedaży przedsiębiorstw. Najogólniej ujmując, wpływ ten jest negatywny, przy czym jest tym mniejszy, im niższa jest stawka. W obowiązujących od 2011 roku polskich rozwiązaniach ma zastosowanie stawka podstawowa na poziomie $23 \%$ oraz stawki obniżone, równe: $5 \%$ i $8 \%$. Zakres przedmiotowy stosowania stawek preferencyjnych jest rozległy, co stanowi konsekwencje przyjęcia bardzo wysokiej stawki podstawowej. Polska

\footnotetext{
${ }^{7}$ Badaniami objęto 50 przedsiębiorstw zróżnicowanych pod względem: przedmiotu prowadzonej działalności, formy prawnej oraz rozmiaru i okresu działalności. Zakres terytorialny badań ograniczono do województwa śląskiego. Badania na zlecenie wykonała w listopadzie i grudniu 2012 roku wyspecjalizowana jednostka Uniwersytetu Ekonomicznego w Katowicach - Centrum Badań i Ekspertyz, wyłącznie dla potrzeb projektu „Strategie podatkowe przedsiębiorstw” (Zespołowy projekt badawczy realizowany w latach 20112013 w Katedrze Finansów pod kierunkiem T. Famulskiej, finansowany z działalności statutowej Uniwersytetu Ekonomicznego w Katowicach). Rezultaty badań całościowo ujęto w pracy zbiorowej, zob.: [Strategie podatkowe ..., 2013].
} 
na tle innych krajów członkowskich Unii Europejskiej sytuuje się w grupie krajów o najwyższych stawkach podstawowych ${ }^{8}$ (tabela 4.).

TABELA 4.

Stawki podatku VAT w krajach Unii Europejskiej (1 stycznia 2014 roku)

\begin{tabular}{|l|c|c|}
\hline \multicolumn{1}{|c|}{ Kraj } & Stawka podstawowa & Stawki zredukowane \\
\hline Austria & 20 & $10 ; 12$ \\
Belgia & 21 & $6 ; 12$ \\
Bułgaria & 20 & 9 \\
Chorwacja & 25 & $5 ; 13$ \\
Cypr & 19 & $5 ; 9$ \\
Czechy & 21 & 15 \\
Dania & 25 & - \\
Estonia & 20 & 9 \\
Finlandia & 24 & $10 ; 14$ \\
Francja & 20 & 2,$1 ; 5,5 ; 10$ \\
Grecja & 23 & 6,$5 ; 13$ \\
Hiszpania & 21 & $4 ; 10$ \\
Holandia & 21 & 6 \\
Irlandia & 23 & 4,$8 ; 9 ; 13,5$ \\
Litwa & 21 & $5 ; 9$ \\
Luksemburg & 15 & $3 ; 6 ; 12$ \\
Lotwa & 21 & 12 \\
Malta & 18 & $5 ; 7$ \\
Niemcy & 19 & 7 \\
Polska & 23 & $5 ; 8$ \\
Portugalia & 23 & $6 ; 13$ \\
Rumunia & 24 & $5 ; 9$ \\
Słowacja & 20 & 10 \\
Słowenia & 22 & 9,5 \\
Szwecja & 25 & $6 ; 12$ \\
Węry & 22 & $5 ; 18$ \\
Wielka Brytania & $5 ; 10$ \\
Włochy & 22 & 5 \\
\hline
\end{tabular}

Źródło: opracowanie własne na podstawie: [VAT Rates Applied..., 2014, s. 3].

Rozpatrywany podatek w założeniu obciąża ostatecznego nabywcę, czyli konsumenta. Z uwagi na powszechność stosowania stawka podstawowa wpływa na ogólny poziom cen. Zbyt wysoka nie jest pożądana, gdyż wiąże się z ogólnym ograniczeniem możliwości konsumpcyjnych obywateli, w szczególności mniej zamożnych. Władza publiczna, dążąc do ochrony podstawowej konsumpcji gospodarstw domowych, może stosować stawki obniżone na określone dobra, w tym artykuły pierwszej potrzeby. Pre-

${ }^{8}$ Szersze studium porównawcze zawiera opracowanie: [Improving VAT/GST ..., 2013]. 
ferencyjne traktowanie konsumenta jest jednocześnie protekcją dla producenta (usługodawcy), ponieważ daje możliwość ustalenia odpowiednio niższych cen? ${ }^{9}$. W praktyce jak najniższymi stawkami podatku od towarów i usług są zatem zainteresowani nie tylko konsumenci, ale i przedsiębiorstwa. Dodatkowo łączy się to z faktem, że nie zawsze jest możliwe przerzucenie ciężaru podatku od towarów i usług na konsumenta przez podwyższenie ceny. Możliwości te są uwarunkowane rynkowym mechanizmem kształtowania się cen [Famulska, 2007, s. 152-153].

Szczególna sytuacja w finansach przedsiębiorstwa występuje w przypadku zastąpienia przez ustawodawcę stawki obniżonej stawką podstawową lub podwyższenia stawek w ogóle. Potwierdzily to przywoływane badania w grupie 50 przedsiębiorstw. W Polsce stawki podatku od towarów i usług podwyższono od 1 stycznia 2011 roku, stąd większość badanych doświadczyła ich wzrostu. Przedsiębiorstwa zapytane o reakcję na tę zmianę warunków działalności wskazały przede wszystkim na zwiększenie cen sprzedaży (tabela 5.). Dominująca część przedsiębiorstw, których dotyczył wzrost stawki podatku od towarów i usług, dokonała podwyższenia cen stosownie do wzrostu stawki. Jednakże w wielu przypadkach, gdyż prawie 30\% ogółu wskazań, nie dokonała się całkowita przerzucalność w przód. W jej miejsce albo nastapiło podwyższenie cen mniejsze niż wynikałoby to ze wzrostu stawki, albo zastosowano przerzucalność wstecz, czyli na dostawców. W pięciu sytuacjach wskazano, że wyższy podatek od towarów i usług został pobrany „kosztem” przedsiębiorstwa (obniżenie ceny netto, zmniejszenie rozmiarów sprzedaży itp.), co pozostaje w sprzeczności z ekonomiczną istotą tego podatku.

Identyfikując potencjał podatku od towarów i usług w aspekcie strategii podatkowej przedsiębiorstwa, należy przede wszystkim odnotować, że sama istota tego podatku ogranicza rozważany potencjał. Podatek od towarów i usług jest bowiem obciążeniem konsumpcji (konsumenta), natomiast w system jego poboru sa właczone wszystkie kolejne ogniwa obrotu gospodarczego. Zatem dotyczy wszelkich przedsiębiorstw, względem których w założeniu ma pozostawać neutralnym. Jednak nie oznacza to, że w jego konstrukcji nie ma uregulowań, w których są zawarte możliwości wyboru, a tym samym jest spełniony warunek wyjściowy do stosowania strategii podatkowej [Strategie podatkowe..., s. 147]. Główne płaszczyzny wyboru przewidziano dla małych i średnich przedsiębiorstw, w tym: status podatnika (opodatkowanie lub zwolnienie) ${ }^{10}$ oraz status małego podatnika (rozliczanie kwartalne

9 Władza publiczna analizuje wartość preferencji podatkowych, w tym w podatku od towarów i usług, zob.: [Preferencie podatkowe w Polsce (4), 2014, s. 31-38].

10 Status przedsiębiorstwa jako podatnika od towarów i usług w ujęciu potencjalnym nie jest równoznaczny z faktycznym. Dla pewnej grupy przedsiębiorstw istnieje bowiem prawo wyboru: opodatkowanie lub zwolnienie. Polski ustawodawca wykorzystał możliwość zastosowania zwolnień dla drobnych przedsiębiorców przewidzianych w przepisach unijnych [Dyrektywa 2006/112/WE Rady z dnia 26 listopada 2006 roku w sprawie wspólnego systemu podatku od wartości dodanej (Dz. U. UE z 2006 roku L 347/1 z późn. zm., art. 280)]. Prawo do zwolnienia uzależniono od wartości sprzedaży. Drobnym przedsiębiorca, w przypadku którego zwalnia się od podatku dokonywana przez niego sprzedaż, jest podatnik, u którego wartość sprzedaży nie przekroczyła łącznie w poprzednim roku podatkowym kwoty 150000 zł, przy czym do wartości sprzedaży nie wlicza się kwoty podatku [Ustawa ₹ dnia 11 marca 2004 roku ..., 2011]. 
albo rozliczanie metodą kasowa) ${ }^{11}$. Zaproponowane przez ustawodawcę preferencje w podatku od towarów i usług nie w każdym konkretnym przypadku są korzystne.

TABELA 5.

Reakcja badanych przedsiębiorstw na wzrost stawki podatku od towarów i usług

\begin{tabular}{|l|c|c|}
\hline \multicolumn{1}{|c|}{ Wzrost stawki i reakcja } & \multicolumn{2}{c|}{ Wskazania } \\
\cline { 2 - 3 } & ilość & \% badanych \\
\hline $\begin{array}{l}\text { Przedsiębiorstwa dotyczył wzrost stawki (sta- } \\
\text { wek) VAT }\end{array}$ & 37 & 74,0 \\
\hline $\begin{array}{l}\text { Przedsiębiorstwa nie dotyczył wzrost stawki } \\
\text { (stawek) VAT }\end{array}$ & 7 & 14,0 \\
\hline Brak wskazania & 6 & 12,0 \\
\hline \multicolumn{1}{|c|}{ Razem } & 50 & 100,0 \\
\hline Reakcja na wzrost stawki* & 31 & $\begin{array}{c}\text { \% przedsiębiorstw, których } \\
\text { dotyczył wzrost stawki VAT }\end{array}$ \\
\hline $\begin{array}{l}\text { Podwyższenie cen sprzedaży stosownie do } \\
\text { wzrostu stawki VAT }\end{array}$ & 3 & 83,78 \\
\hline $\begin{array}{l}\text { Podwyższenie cen sprzedaży mniej niż wzrost } \\
\text { stawki VAT }\end{array}$ & 0 & 0,00 \\
\hline $\begin{array}{l}\text { Podwyższenie cen sprzedaży więcej niż wzrost } \\
\text { stawki VAT }\end{array}$ & 3 & 8,11 \\
\hline Negocjowanie niższych cen z dostawcami & 5 & 13,51 \\
\hline Wyższy VAT został pobrany „kosztem” firmy & & \\
\hline
\end{tabular}

* Możliwe więcej niż 1 wskazanie

Źródło: opracowanie własne na podstawie: [Strategie podatkowe ..., 2013, s. 169].

11 Zgodnie z Ustawa o podatku od towarów i ustug [Ustawa z dnia 11 marca 2004 roku ..., 2011, art. 2 pkt 25.], małym podatnikiem jest podatnik, u którego wartość sprzedaży (wraz z kwota podatku) nie przekroczyła w poprzednim roku podatkowym wyrażonej w złotych kwoty odpowiadającej równowartości 1200000 euro. W przypadku podatnika prowadzącego przedsiębiorstwo maklerskie, zarządzającego funduszami inwestycyjnymi, będącego agentem, zleceniobiorcą lub osobą świadczącą usługi o podobnym charakterze, z wyjątkiem komisu, u którego kwota prowizji lub innych postaci wynagrodzenia za wykonane usługi (wraz z kwotą podatku) nie przekroczyła w poprzednim roku podatkowym wyrażonej w złotych kwoty odpowiadającej równowartości 45000 euro. Przeliczenia kwot wyrażonych w euro dokonuje się według średniego kursu euro ogłoszonego przez Narodowy Bank Polski na pierwszy dzień roboczy października poprzedniego roku podatkowego, w zaokragleniu do 1000 zł. 
TABELA 6. Liczba małych podatników podatku od towarów i usług w latach 2005-2013

\begin{tabular}{|c|c|c|c|c|c|c|c|c|c|c|}
\hline Lp. & Wyszczególnienie & 2005 & 2006 & 2007 & 2008 & 2009 & 2010 & 2011 & 2012 & 2013 \\
\hline 1. & $\begin{array}{l}\text { Liczba podatników } \\
\text { podatku od towa- } \\
\text { rów i usług, tzw. } \\
\text { podatników VAT } \\
\text { czynnych }\end{array}$ & 1373019 & 1417050 & 1480782 & 1540789 & 1588536 & 1569439 & 1603520 & 1605 & 1616849 \\
\hline 2. & $\begin{array}{l}\text { Liczba małych po- } \\
\text { datników podatku } \\
\text { od towarów i usług } \\
\text { - podmioty speł- } \\
\text { niające kryteria }\end{array}$ & 1327339 & 1374069 & 1419851 & $\mid 1470209$ & 1489938 & 1525997 & 1530963 & 1542155 & 1556135 \\
\hline 3. & $\begin{array}{l}\text { Liczba małych po- } \\
\text { datników podatku } \\
\text { od towarów i usług } \\
\text { rozliczających się } \\
\text { kwartalnie (VAT- } \\
\text { 7K) }\end{array}$ & 68484 & 80204 & 100040 & 117148 & 149200 & 178784 & 208019 & 238438 & 279893 \\
\hline 4. & $\begin{array}{l}\text { Liczba małych po- } \\
\text { datników podatku } \\
\text { od towarów i usług, } \\
\text { którzy wybrali me- } \\
\text { todę kasową }\end{array}$ & 6690 & 6996 & 7313 & 7712 & 8721 & 9181 & 9263 & 9128 & 14865 \\
\hline 5. & $\begin{array}{l}\text { Dynamika „1” rok } \\
2005=100\end{array}$ & 100 & 103,21 & 107,85 & 112,22 & 115,70 & 114,31 & 116,79 & 116,96 & 117,76 \\
\hline 6. & $\begin{array}{l}\text { Dynamika ,2” rok } \\
2005=100\end{array}$ & 100 & 103,52 & 106,97 & 110,76 & 112,25 & 114,97 & 115,34 & 116,18 & 117,24 \\
\hline 7. & $\begin{array}{l}\text { Dynamika ,3” rok } \\
2005=100\end{array}$ & 100 & 117,11 & 146,08 & 171,06 & 217,86 & 261,06 & 303,75 & 348,17 & 408,70 \\
\hline 8. & $\begin{array}{l}\text { Dynamika „4" rok } \\
2005=100\end{array}$ & 100 & 104,57 & 109,31 & 115,28 & 130,36 & 137,23 & 138,46 & 136,44 & 222,20 \\
\hline
\end{tabular}

Źródło: opracowanie własne na podstawie sprawozdań wewnętrznych Ministerstwa Finansów (dane niepublikowane).

Analiza materiału empirycznego z lat 2005-2013 (tabela 6.) pozwala zauważyć, że liczba podatników podatku od towarów i usług, którzy spełniają kryterium małego podatnika, jest bardzo duża. W rozpatrywanych latach podmioty te stanowiły średnio około $96 \%$ ogółu tzw. podatników VAT czynnych. Spośród tej dużej liczby z rozliczenia kwartalnego korzysta systematycznie z roku na rok więcej podatników. O ile w 2005 roku podmioty rozliczające się kwartalnie stanowiły tylko około $5 \%$ małych podatników, o tyle w roku 2013 było to już prawie 18\%. Ta tendencja może utrzymać się i świadczy o wzroście świadomości podatkowej w przedsiębiorstwach, w tym w zakresie możliwości wyboru okresu rozliczeniowego w podatku od towarów i usług. Stosowanie elementów strategii podatkowej przez przedsiębiorstwa znajduje również potwierdzenie w liczbie podatników, którzy wybrali metodę kasowa. Ich liczba w 2013 była ponad dwukrotnie wyższa niż w 2005 roku. Wzrost ten jest odpowiedzią na korzystną zmianę regulacji dotyczących metody kasowej. Nie zmienia to faktu, że preferencja, z której korzysta niespełna $1 \%$ uprawnionych, wymaga dalszej korekty ze strony ustawodawcy. 
Można spodziewać się zmian o wymiernych, pozytywnych skutkach pod względem płynności finansowej przedsiębiorstwa.

\section{Podsumowanie}

Podatki są ważnym uwarunkowaniem funkcjonowania przedsiębiorstw. Zakres ich oddziaływania jest zróżnicowany w zależności od rodzaju podatku i jego umiejscowienia w finansach przedsiębiorstwa. Zawsze istotną kwestią pozostaje wielkość i termin rozliczenia określonego ciężaru podatkowego. Skutki danego podatku w przedsiębiorstwie są także zależne od reakcji na to obciażenie. Reakcje te mogą być różne, przy czym z punktu widzenia przedsiębiorstwa za pożądane należy przyjąć stosowanie strategii podatkowej. Rozpatrywany przykład podatku od towarów i usług wskazuje, że podatek ten pozostaje ciężarem dla przedsiębiorstw tak w aspekcie uszczerbku finansowego, jak i płynności finansowej oraz w sensie technicznym, który wiąże się z umiejętnościa prawidłowego rozliczenia. Jednocześnie jest to regulacja o ograniczonym potencjale pod względem stosowania strategii podatkowej.

Dużym wyzwaniem jest już samo prawidłowe ustalenie i wywiązanie się ze zobowiązania podatkowego z jego tytułu. Skomplikowane regulacje implikują trudności w identyfikacji możliwości stosowania strategii i samym jej stosowaniu. Należy oczekiwać, że zauważalna aktywność przedsiębiorstw związana ze strategia podatkową w zakresie podatku od towarów i usług będzie rozszerzać się wraz ze wzrostem wiedzy podatkowej.

\section{Literatura}

Dyrektywa 2006/112/WE Rady z. dnia 26 listopada 2006 r.w sprawie wspólnego systemu podatku od wartości dodanej (Dz. U. UE z 2006 roku, L 347/1, z późn. zm.).

European Commission 2014 VAT Rates Applied in the Member States of the European Union, Brussels.

Famulska T. 1998 Oddriatywanie systemu podatkowego na rynek finansony, Akademia Ekonomiczna, Katowice.

Famulska T. 1993 System opodatkowania przedsiebiorstw w Polsce, Akademia Ekonomiczna, Katowice.

Famulska T. 2007 Teoretyczne i praktyczne aspekty funkcjonowania podatku od wartości dodanej, Akademia Ekonomiczna, Katowice.

Giachetti R. 2010 Design of Enterprise Systems. Theory, Architecture and Methods, CRC Press, Boca Raton.

Gomułowicz A. 2013 Podatki a etyka, Wolters Kluwer Polska S.A., Warszawa.

Improving VAT/GST - Designing a Simple and Fraud-proof Tax System 2014, M. Lang, J. Lejeune (eds.), International Bureau of Fiscal Documentation, Amsterdam.

Kudła J. 2013 Ekonomia opodatkowania miedrynarodowego, Difin, Warszawa.

Oddriatywanie instytugii interpretagi podatkonych na finanse przedsiebiorstw 2013, T. Famulska (red.), Difin, Warszawa. 
Preferencje podatkowe w Polsce (4) 2014, Ministerstwo Finansów, Warszawa.

Strategie podatkowe przedsiębiorstw, B. Ciupek, T. Famulska (red.), Uniwersytet Ekonomiczny, Katowice 2013.

Straty Skarbu Państwa w VAT 2013, PricewaterhouseCoopers Sp. z o.o., Warszawa.

Szczodrowski G. 2012 Polski system podatkowy, Wydawnictwo Naukowe PWN, Warszawa.

Ustawa z. dnia 11 marca 2004 roku o podatku od towarów i ustug (Dz. U. z 2011 r., Nr 177, poz. 1054 z późn. zm.).

Witczak R. 2013 Zastosowanie metod szacowania podstawy opodatkowania w podatkach dochodowych jako sposób przecinviriatania oszustom podatkowym, [w:] Konsekwencje zmiany obciażeń podatkouych w Polsce, J. Głuchowski, K. Piotrowska-Marczak, J. Fila (red.), Difin, Warszawa. 